\title{
The Construction of Crime: The Presumption of Blue-Collar Guilt and White-Collar Innocence
}

\section{Lisa Marriott}

Victoria Business School, Victoria University of Wellington, New Zealand

E-mail: lisa.marriott@vuw.ac.nz

This study examines a recent legislative change in New Zealand social policy that provides for the partners of people engaging in welfare fraud to be prosecuted for the crime and to be jointly liable for the debt generated from the crime. This situation applies where the partner knew, or ought to have known, of the fraud. This approach may be contrasted with the treatment of the partners of those who engage in tax evasion, or other forms of financial crime, who are not liable for prosecution or any debt resulting from the offence.

Discrimination of those on welfare is well-established. The article highlights the extent to which welfare beneficiaries are now targeted for greater punitive measures in New Zealand and the increasing criminalisation of welfare in the country. The practices outlined appear to contravene the New Zealand Human Rights Act. Moreover, these practices are not aligned with the basic provisions of criminal law: that a guilty mind and a positive act are present for a crime to be committed. The study draws attention to issues of equity, knowledge of crime, and the construction of crime and criminals in the New Zealand justice system.

\section{Introduction}

It is well established across a range of jurisdictions that those engaging in blue-collar crime can expect to receive harsher penalties in the justice system than those engaging in white-collar crime, where equivalent levels of harm are present. New Zealand is no different: welfare fraud is investigated at a higher rate than tax evasion; welfare fraudsters are more likely to be prosecuted than tax evaders; and those convicted of welfare fraud will receive a harsher sentence than those convicted of tax evasion for equivalent levels of financial harm (Marriott, 2012; Marriott, 2014a).

The purpose of this study is to highlight the criminalisation of welfare receipt in New Zealand. While evidence already exists of different treatments of welfare beneficiaries in the justice system in New Zealand, this is the first example of legislative provisions that overtly facilitate a different outcome for a conceptually identical offence.

Welfare fraud and tax evasion are used for comparison in this study as they are conceptually similar. Both are deliberate, financial offences that result in the same outcome: fewer resources for the government. Moreover, both result in a quantifiable measure of harm to society. Tax evasion and welfare fraud have been successfully compared in prior studies (e.g. Cook, 1989). However, some differences exist in the two offences. Knowledge is required for tax evasion: typically sophisticated tax evasion requires some expertise with the tax system. Furthermore, tax evaders are likely to have resources: typically, income or other withholding taxes have been collected before the 
tax is unpaid. Conversely, welfare fraud is more likely to be committed by those without resources. Also relevant is the economic impact of each offence. In 2013, detected welfare fraud in New Zealand totalled NZ\$26 million (Ministry of Social Development, 2013a: 28) while detected tax evasion totalled NZ\$812 million (Inland Revenue Department, 2013: 27) - thirty-one times the value of welfare fraud.

The study focuses on recent legislative changes in New Zealand that facilitate debt recovery from, and prosecution of, the partners of those who engage in welfare fraud. The changes require the partners to knowingly benefit from the fraud, but also extend to situations where the partner 'ought to have known' they were benefitting. Thus, the changes remove the requirement for the partner who did not actively engage in the fraudulent activity to have performed a deliberate act prior to becoming liable for the offending. The extension of liability applies only to welfare beneficiaries. Reference is made to the treatment of tax evaders in order to illustrate the increasing criminalisation of welfare receipt in New Zealand. Inclusion of tax evaders also assists with highlighting the legislated differentiation of those on welfare from all other citizens in society. The creation of different rules in society for different 'groups' suggests identification of a 'problem' category of people, which subsequently has the effect of overlooking other forms of offending, such as white-collar crime (Wacquant, 2009: xix). This is particularly the case when the groups who are selected for harsher treatment are the 'working class and in particular the dispossessed members of stigmatized groups' (Wacquant, 2009: xvi).

The study is structured as follows. The next section outlines the literature pertaining to differences in the way blue- and white-collar crime is treated in the justice system. The third section outlines the legislative changes in New Zealand that now allow for the partners of those who have been convicted of welfare fraud to be liable for the same offence. The fourth section engages in a discussion on the impact of the changes, and the fifth section concludes.

\section{Background}

The different treatment of white- and blue-collar offenders in the justice system is wellestablished. This section discusses these literature findings and explores the research that has captured the views of society on the two types of offending. Reference to the terms 'blue- and white-collar' crime is usually intended to reflect crimes undertaken by those who have fewer or greater resources, respectively. Reference to blue- and white-collar crime in this study refers to welfare fraud and tax evasion, respectively. It is acknowledged that tax evasion may be committed by individuals that are more typically considered to be blue-collar (e.g. trades people). However, in New Zealand, employees do not file tax returns unless they have income that is not taxed at source (e.g. income from rental properties). Therefore, those who are self-employed, those who have certain income from capital or those who have untaxed overseas income are those with the greatest opportunity to engage in tax evasion. While these people may not be elites in the traditional use of the word, they are not typically in the 'lower' group of society that is associated with those on welfare.

The differences in treatment of those engaging in welfare fraud and tax evasion in New Zealand are evident. In New Zealand, investigations for fraud take place with around 0.1 per cent of taxpayers and 5 per cent of those on welfare (Marriott, 2014a). In recent years, there have been sixty to eighty criminal prosecutions annually for tax evasion 
and 800-1,000 cases of welfare fraud prosecution (Marriott, 2014a). The likelihood of receiving a custodial sentence for welfare fraud is approximately three times as high as tax evasion, for around one-quarter of the quantum of fraudulently obtained funds (Marriott, 2014a).

\section{Different outcomes for offenders}

Over seventy years ago, Sutherland's research suggested that differences in outcomes for white- and blue-collar crime may be driven by the fact that respected business and professional people had access to power and resources, such as legal representation, that is not available to 'crime in the lower class, composed of persons of low socioeconomic status' (1940: 1). Subsequent to Sutherland's research, numerous research outputs have reported different outcomes for offenders classified as committing blue- or white-collar offences, with white-collar offenders receiving more lenient treatment in the justice system than blue-collar offenders (Sutherland, 1949; Weisburd et al., 1991; Nelken, 1997; Croall, 2001; Cook, 2002; Marston and Walsh, 2008; Gustafson, 2009; Marriott, 2014a). The point is well made by Reiman and Leighton (2013) in their book titled The Rich get Richer and the Poor get Prison. Reiman and Leighton argue that the criminal justice system favours the wealthy by excluding activities that are more likely to be undertaken by the most advantaged in society. However, it is often these activities that generate more harm than other activities that will be pursued more vigorously in various stages of the criminal justice system. Not only do harsher sentences result from blue-collar offending, there are considerably greater resources involved in the investigation and prosecution of welfare fraud than other financial offending against the state (Henman and Marston (2008). Meanwhile, research suggests that the public would like to see more resources allocated to addressing white-collar crime (Holtfreter et al., 2008).

\section{Different views of white- and blue-collar crime in society}

Historically, views of society have tended to capture a perspective where tax evasion is viewed as less serious than welfare fraud, or other forms of financial fraud. For example, many studies have asked individuals to rank offences based on the seriousness of the offence. A New Zealand study (Gupta, 2006) finds that welfare fraud is ranked eighth in seriousness, with insurance fraud ranked eleventh and tax evasion ranked twelfth, just ahead of running a red traffic light at thirteenth. Similar findings are found in a study by the Australian Institute of Criminology (1986), where social security fraud was viewed as significantly more serious than tax evasion or medical insurance fraud, despite the sum of money in the social security fraud being 20 per cent of the fraud in the tax and insurance fraud scenarios.

Typically, studies find that the public view white-collar crime as less serious than blue-collar crime (e.g. Rossi et al., 1974; Cullen et al., 1982; Evans and Kelley, 2001; McIntosh and Veal, 2001; Orviska and Hudson, 2002; Marston and Walsh, 2008; Smith et al., 2011); this is despite the greater amounts involved in white-collar crime. Evans and Kelley's (2001) study reports that among a sample of twenty-nine countries, welfare fraud was more strongly condemned than tax cheating in every country. While there is some suggestion that attitudes have changed towards white-collar crime (e.g. Cullen 
et al., 2009), often these results report on the findings from corporate crime, rather than the individual activity reported on in this study.

Research by Bright (1978) reports on a high level of tolerance in society towards tax evasion. This view is visible across a range of research outputs, with Croall, for example, reporting that tax evasion is often viewed as 'elite crime or crimes of the powerful' (2001: 11). Of relevance to this study is the finding that different views of welfare offending extend beyond disapproval of fraud, into disapproval of welfare receipt in general. For example, Bright notes society's disapproval of the 'hedonistic transgressions of the unemployed', noting that welfare recipients are 'presented as parasites demanding social security while making no contribution to the economy' (1978: 161). Chunn and Gavigan make similar observations in their Canadian study, writing that 'welfare fraud became welfare as fraud. Thus, poverty, welfare and crime were linked' (2004: 220). The recent evolution of television 'documentaries' of those in receipt of welfare (such as Struggle Street in Australia and Benefits Street in the United Kingdom) has assisted with the promulgation of negative attitudes towards welfare recipients. This type of exposure promotes excessive public attention on the 'duties and responsibilities' of those at the 'bottom end' of society, while reducing attention on those at the 'top end' when they fail to meet their obligations (Cook, 2006: 12).

These practices serve to further marginalise a group within society by supporting traditional stereotypes of welfare recipients. The narrative that is communicated is that welfare recipients: cannot be trusted; will abuse the system if given the opportunity; and that increased state-sanctioned monitoring, intrusion and punishment is justified for welfare recipients. It is worth observing that reports from the United Kingdom suggest that under-payments total 31 per cent of errors in payments made to welfare recipients in 2013 (Work and Pensions Committee, 2014). Underpayments are not reported in New Zealand, which serves to further reinforce the dominant view that all errors are overpayments and fraudulent in nature.

\section{Welfare fraud in New Zealand}

In New Zealand, relationship fraud 'occurs when a person who is living in a de facto, marital or civil union relationship claims a single or sole parent rate of benefit for which they are not eligible' (Scott, 2012: 5). Relationship fraud may occur when the Ministry of Social Development is not advised of changes to a relationship where one of the partners is receiving a benefit. For individuals to be considered to be in a relationship, the Ministry of Social Development requires there to be a 'degree of companionship' where two people are committed to each other and financially dependent on each other (Ministry of Social Development, 2015).

From 7 July 2014, amendments to the Social Security Act 1964 result in partners ${ }^{1}$ of those who receive overpayments of welfare benefits, as a result of relationship fraud, becoming potentially jointly and severally liable for the debt generated from the fraud committed by their partners. Moreover, criminal liability for the fraud may be extended to the partner of the individual who committed the fraud. Prior to this change of legislation, only the person who received the benefit was liable for the welfare debt and prosecution was only actionable against the person engaging in the fraudulent activity. Under the amended legislation, the liability arises where the partner of the beneficiary who has committed the fraud has benefited from the fraud either knowingly, or where they ought 
to have known they were benefiting from fraud. ${ }^{2}$ The partner of the beneficiary who has committed the fraud does not need to know the precise amount of the fraud or how the fraud occurred.

\section{Liability for offending}

Prior to the introduction of the changes to the Social Security Act 1964 in 2014, the Ministry of Social Development had two options whereby partners could be held to account for relationship fraud. These options were when the partner (not directly committing the fraud) had made a false or misleading statement about circumstances, which resulted in the individual committing the fraud receiving funds beyond their entitlement. ${ }^{3}$ This allowed for recovery action against the partner on the basis that they were jointly and severally liable for the debt. ${ }^{4}$ The second option was the capacity for the Ministry of Social Development to prosecute the partner who was not directly engaged in the fraudulent activity, again where misleading or false information had been provided. ${ }^{5}$ Scott notes that the Ministry of Social Development was typically unable to use either of these options, as the partner who was not actively engaged in the fraud usually had no contact with the Ministry, and prosecution was only able to take place when evidence existed that the partner had 'incited or counselled their partner to commit the offence or where a spouse or partner makes false or misleading statements to MSD [the Ministry of Social Development]' (2012: 6). In most cases, this evidence was not available. Moreover, this situation required positive action to be taken by the individual who was not directly involved in the fraudulent activity.

The Social Security (Fraud Measures and Debt Recovery) Amendment Act 2014 introduces the concept that:

a person (the spouse or partner) commits an offence who

(a) is a spouse or partner of a person (the beneficiary) who obtains an excess amount by fraud; and

(b) benefits directly or indirectly from the amount or a part of it knowing that, or being reckless about whether, the amount or part is an amount or part

(i) in excess of the amount to which the beneficiary is by law entitled or to which the beneficiary has no entitlement; and

(ii) obtained by the beneficiary by fraud. ${ }^{6}$

Section $127 \mathrm{~A}(2)$ expands subsection (1)(b) to explain that this section:

applies to the amount or part even if the spouse or partner:

(a) does not benefit from it knowingly; and

(b) does not know at all or exactly its value; and

(c) does not know, or (as the case requires) is not reckless about, the precise way in which it was obtained by the beneficiary by fraud.

Thus, liability for the fraud extends to where the partner did not benefit from the fraudulent activity; does not know the value of the crime; and did not know or was not reckless about how the funds were obtained. Reference to an 'excess amount' is where 
the beneficiary receives any payment to which they are not entitled to by law. A person would be considered to be reckless 'where they know that it is a risk that money is being derived from welfare fraud and they unreasonably proceed regardless' (Ministry of Social Development, 2013c: 17). This change results in the partner of the person engaging in the welfare fraud being liable to prosecution for the offence.

\section{Debt collection}

Changes to the Social Security Act 1964 were also made in relation to the collection of welfare debts. Legislative changes result in apportionment of the debt between partners, whereby the partner who did not commit the welfare fraud can become liable for the proportion obtained by fraud. The requirement is that the benefit is apportioned between partners, and the partner who did not commit the fraud: 'knew, or ought to have known, of the fraud'. ${ }^{7}$

Under section 86 of the Social Security Act 1964, the Chief Executive of the Ministry of Social Development has a duty to 'take all reasonably practicable steps to recover a debt referred to in section $85 \mathrm{~A}^{\prime}$. Debts outlined in section $85 \mathrm{~A}$ of the Act include payments that are debts to the Crown including penalties, debts due for repayment, advances of benefits and other overpayments. Under section 86(2) of the Social Security Act 1964, where a person has obtained payments in excess of their entitlement as a result of fraud, the Chief Executive has the discretion to recover a penalty from the person committing the fraud. This penalty may be up to three times the value of the fraudulently obtained benefit. In the three most recent years for which data are available, between 120 and 160 people had additional penalties added to their fraud-related debt. Specifically, 121 people in 2011, 160 people in 2012 and 128 people in 2013 received additional penalties. ${ }^{8}$ As a proportion of prosecuted cases, 18 per cent, 22 per cent and 13 per cent of prosecuted cases in 2011, 2012 and 2013, respectively, had additional penalties applied to their debt.

New subsection 86AA provides for the partner who is not engaged in the welfare fraud to be jointly and severally liable for the debt. For the purposes of this recovery, fraud means that the person made a statement knowing it was false in a material way; knowingly said or did something, or omitted to say or do something for the purpose of misleading a welfare officer; or is convicted of a specified offence in relation to that amount. ${ }^{9}$ Liability exists where the partner knowingly benefited from the fraud, either directly or indirectly; or 'ought to have known (even if the spouse or partner did not know) that the spouse or partner was benefiting directly or indirectly from the beneficiary's fraud'. ${ }^{10}$

A total of fifteen submissions were made to the Bill. Submissions raised issues associated with the change that the partner may be fully liable for the excess amount obtained under the fraudulent activity, regardless of the amount that the partner benefited from the fraud. This reflects another change incorporated by the Bill, which made amendments to debt recovery by the welfare agency. The change in the legislation clarified the Ministry of Social Development's (MSD) practice, which is 'that MSD will always seek to recover a debt and actively pursue it until all avenues to recover it have been exhausted' (Scott, 2012: 13). However, in New Zealand welfare debtors were already treated more harshly than other debtors to the Crown, such as tax debtors (Marriott, 2014b). While all debts are not necessarily the result of fraud, in New Zealand tax debt is more likely to be written off in the short term, while welfare debt is more likely to be maintained until it 
can be collected at a future date, such as from the debtor's estate (Marriott, 2014b). This is despite the fact that tax debts, at nearly $\$ 6$ billion, are almost six times the amount of welfare debt. This legislative change makes the rules even more punitive for these welfare debtors.

\section{Additional proposed changes}

Communications from the Office of the Associate Minister for Social Development show further options under consideration by the government for 'special' treatment for welfare recipients. In total, seven initiatives are discussed, one of which was outlined above (splitting fraud debt across partners). The other six initiatives are:

- creating new tools to deal with 'low-trust beneficiaries', such as requiring extra verification of documents or redirecting part of their benefit directly to bill payments;

- creating an interagency approach which will allow targeting people of concern to several agencies';

- moving to full information sharing between the Ministry of Social Development and Inland Revenue;

- making changes to the Code of Conduct under the Social Security Act, which will mean that the Ministry of Social Development will no longer need to inform people that they are being investigated;

- requesting details of someone who can confirm the beneficiary's relationship status; and

- improving the recovery of money, including use of private debt collection, civil court action and use of the Police Asset Recovery teams to seize assets. Moreover, the document states 'if they are not paying back what they owe, we will stop them [at] the border should they attempt to leave the country'. (Borrows, 2013)

When combined with the changes outlined in the previous sub-sections, these 'initiatives' serve to reinforce the punitive approach of the government towards those receiving welfare payments. The issue is captured by Wacquant (2009: xvii) when writing of the newfound will of political elites to emphasize and enforce the sacred border between commendable citizens and deviant categories, the "deserving" and the "undeserving" poor'.

If there is valid reason for targeting the partners of those on welfare on the basis of presumed guilt, then a logical extension is to include the partners of those convicted of tax evasion or other forms of financial fraud where partners are also likely to benefit from the offending. However, there are no proposals to do this, or to extend any of the six initiatives outlined above to any group in society other than welfare recipients.

\section{Discussion}

The objectives of the legislative changes in New Zealand outlined in the third section above are 'to prevent and deter fraud from occurring, encourage compliance with the welfare system, detect fraud quickly, penalise appropriately and recover fraud debt' (Scott, 2012: 6). However, it would appear that these objectives would be equally as desirable for other forms of financial offending, whether against the state or against other individuals or organisations. Perhaps the most obvious comparison is made with tax evasion. It is 
not apparent why the following would not all be desirable objectives: prevention and deterrence of tax fraud, encouraging compliance with the tax system; detecting tax fraud quickly; appropriately penalising tax offending; and recovery of tax debt. However, there has been no suggestion, discussion or debate in relation to extending these legislative changes to any other form of crime. There are no New Zealand cases where partners of tax evaders have been deemed to have knowledge of their partners' tax offences, and prosecuted accordingly. ${ }^{11}$

\section{Equity}

The legislative changes imposed in New Zealand are framed as 'fair and reasonable' for both people in a relationship to be held accountable for the offence where the partner of a beneficiary knew, or ought to have known, they were benefiting from fraud (Ministry of Social Development, 2013b). The foundation of this argument is that, in the absence of both individuals being equally liable for the offending, the individual committing the fraud has sole culpability for the fraud, despite the potential for there to be a partner who may be aware of, and benefiting from, the offending.

It is unclear how 'ought to have known' will be interpreted. As noted by the Ministry of Social Development report on the Bill (Ministry of Social Development, 2013c) there is an objective and a subjective element to this determination. However, the primary concession appears to be 'in cases where the partner did not know and could not have reasonably known that they were benefiting from a fraud, for example, in cases where the beneficiary has successfully concealed the fraud from their partner, the partner will not be liable for the debt' (Ministry of Social Development, 2013c: 14). ${ }^{12}$

Multiple equity issues are raised with the legislative changes in New Zealand. The first is equity between partners, for both tax evasion and welfare fraud. In relation to tax evasion, partners are treated as autonomous individuals. In relation to welfare fraud, partners are treated as either having explicit or implied knowledge of the offending, resulting in potential liability for the crimes of another. The second issue relates to equity between taxpayers. Where taxpayers, partners or those engaging in welfare fraud, do not meet their obligations, other taxpayers either have to increase their tax payments or accept a reduced level of state-provided services. Third, is the issue of equity between tax evaders and welfare fraudsters, as greater opportunities are extended to those who engage in tax evasion to not meet their debt, while welfare fraudsters' debts are pursued to a much greater extent. On the whole, the legislative changes dilute the generally accepted foundation that all individuals in society are treated as equals (Sen, 2009).

\section{Debt recovery}

A further example of the targeting of welfare beneficiaries for discrimination can be found in relation to debt recovery. Section 86(4) of the Social Security Act 1964 already provides for recovery from the estates of a deceased beneficiary any excess amounts of benefit obtained. No similar provision exists for tax debtors. ${ }^{13}$ The amendments to the legislation allow for more punitive debt collection activity for welfare debt than for other debts to the government. There has been no suggestion that partners of those engaging in tax evasion, for example, should be equally liable for the debts of their partner. ${ }^{14}$ 
Government communications pertaining to the debt attribution suggest that the amended approach 'reflects that fraud is involved and taxpayers should be fully recompensed by either or both parties as soon as practicable ${ }^{\prime 15}$ This same approach to other taxpayers' funds, such as unpaid tax, is not visible. Moreover, the debt collection methods for unpaid tax are considerably more lenient than those adopted for welfare debts.

The Ministry of Social Development accepts higher costs to collect welfare debts, incurring costs of NZ\$17.00 to collect $\$ 100$ of welfare debt, while the tax authority incurs $\$ 2.86$ to collect $\$ 100$ of tax debt (Marriott, 2014b). Rather than reflecting different levels of efficiency, the different costs incurred to collect debt can be attributed to higher levels of writing off tax debt, and greater investment in collecting welfare debt. Similar findings are reported in other jurisdictions, such as Gustafson (2009) in the US and Smith et al. (2011) in the United Kingdom.

\section{The extent of the problem}

One of the purposes of the change to the legislation is to 'strengthen measures to combat relationship fraud'. ${ }^{16}$ In 2011/12, 208 cases of relationship fraud were detected across New Zealand out of a total of 327,817 working-age individuals receiving a main welfare benefit at this time: 0.063 per cent (Ministry of Social Development, 2012). Despite the greater economic significance of tax evasion, more attention is directed towards both the prosecution of, and collection of debt from, those who engage in welfare fraud (and potentially the offenders' partners).

In relation to debt recovery, at June 2012, 92 per cent of current MSD clients with debts were repaying by instalments with an average value of NZ\$14.32 per week and 88 per cent of former MSD clients with debts were repaying by instalments with an average value of NZ\$23.27 per week (Marriott, 2014b). By way of comparison, 11 per cent of Inland Revenue Department tax debtors were paying by instalment. These figures suggest that debt recovery is less problematic with MSD clients than Inland Revenue Department clients. Nonetheless, greater resources are invested in collecting the debt associated with welfare.

A further factor of interest in the New Zealand policy change context is that the Cabinet Papers related to the legislative changes show no positive revenue impact from the amendments. Instead, they show additional costs of NZ\$1.2 million (Office of the Associate Minister of Social Development, 2012). Thus, the policy changes do not expect increased revenue from fraud recovery or, extrapolating from the absence of positive revenues, a reduction in the number of cases of fraud.

\section{Human rights}

In New Zealand, guidance is provided by the Department of Prime Minister and Cabinet for public officials writing cabinet papers for government departments and agencies. This guidance specifies that 'when developing policy proposals, consideration must be given to their consistency with the New Zealand Bill of Rights Act 1990 and the Human Rights Act 1993 and comment included in the Cabinet paper'. ${ }^{17}$ Alternatively, the cabinet papers may include information 'on any justifications for the policy infringing a right or a freedom' ${ }^{18}$ 
Under the New Zealand Bill of Rights Act 1990, the Attorney-General is required to report to Parliament in situations where a Bill appears to be inconsistent with any of the rights and freedoms contained in the New Zealand Bill of Rights Act 1990. ${ }^{19}$ Advice provided by the Ministry of Justice (Ministry of Justice, 2011) concludes that the Bill was consistent with the rights and freedoms affirmed in the Bill of Rights Act. Accordingly the Attorney-General does not need to report to Parliament on the Bill. However, one of the key issues was not considered. Under the New Zealand Bill of Rights Act, everyone has the right to freedom from discrimination on the grounds outlined in the Human Rights Act 1993. ${ }^{20}$ One of the prohibited grounds of discrimination in the Human Rights Act is employment status, which means: 'being unemployed; or being a recipient of a benefit under the Social Security Act 1964 or an entitlement under the Accident Compensation Act 2001'. ${ }^{21}$ The changes would also appear inconsistent with this requirement by targeting those on welfare benefits, or associated with those on welfare benefits, for special treatment in the justice system.

The human rights component in the Cabinet Papers relating to this issue was redacted. A request was made for the redacted information under the Official Information Act 1982. When the redacted information was released, both Cabinet Papers contained an acknowledgement that the policy proposals:

may be inconsistent with the New Zealand Bill of Rights Act 1990 (NZBoRA) and the Human Rights Act 1993 in relation to the freedom from discrimination. This is because the proposals relating to spouses and partners accountable for relationship fraud may raise issues in terms of the right to justice and discrimination on the grounds of family and marital status.

Both cabinet papers also claim that the limitations that may be imposed are arguably justifiable. However, the Ministry of Justice's final view on whether the proposals are consistent with the NZBoRA will not be known until the legislation has been drafted and considered' ${ }^{22}$ No further discussion is evident on the potential for this legislation to be inconsistent with the Bill of Rights Act or the Human Rights Act.

\section{Knowledge and action}

As noted by Simester and Brookbanks 'if a person is not to blame when something goes wrong, the censure of the criminal law is not appropriate' (2012: 8). Simester and Brookbanks (2012: 8) continue to explain that the presence of fault is required with criminal activity and this is achieved by 'including within every criminal offence some element that reflects culpability'. This is reflected in the requirement for criminal liability to demonstrate mens rea - a guilty mind. The introduction of criminal liability where a person ought to have known of the activity of another person removes the historical expectation that the criminal action will be undertaken with knowledge and intent. Alternatively, reckless behaviour may also suggest culpability. However, it cannot be argued that an individual is reckless in the absence of any positive action. Simester and Brookbanks (2012: 10) summarise this as follows:

Without at least some form of fault, a defendant should not be convicted of a crime. This proposition is reflected in New Zealand's criminal law where, in the absence of advertence to the harm (or, in some cases, of negligence), a defendant must be acquitted of any serious criminal offence. 
A second requirement for a person to be held criminally liable for an offence is the actus reus, which requires the person to have caused or be responsible for the crime. Simester and Brookbanks (2012: 44) write 'normally, the actus reus doctrine requires an action of some sort; something done by the defendant'. Moreover 'standard legal doctrine stipulates that the behaviour requirement is a requirement of positive action by the defendant' (Simester and Brookbanks, 2012: 45). This is expanded as: 'behaviour specified in an actus reus can prima facie be satisfied only by a positive act on the part of the defendant, and not by the defendant's omission'. The absence of positive action was highlighted in submissions to the legislation, including those of the Law Society and the New Zealand Labour Party. ${ }^{23}$ The submission from the New Zealand Law Society, observes 'absent a positive act that would normally ground criminal liability ... the justification for criminal liability is not apparent' (New Zealand Law Society, 2013: 6). Therefore, validity of the legislative change exists insofar as there is no positive action necessary to establish culpability for the crime.

\section{The construction of crime and criminals}

Cook observes that society views 'most welfare benefit claimants as wilfully idle, 'undeserving' and lacking in moral fibre. By contrast, taxpayers are represented as victims: victims of the idle poor (who are financed by the taxpayer) and victims of the state bureaucracy of taxation itself' (1989: 11). As noted by Mosher and Hermer (2010: 18), terms such as 'cheats' and 'criminals' are frequently used to describe those on social assistance, even in the absence of any suggestion of any criminal activity. Frequent messages are seen on the need to 'crack down' and 'get tough' on welfare beneficiaries (Mosher and Hermer, 2010: 18). Mosher and Hermer observe that this results in the 'obvious and logical deduction ... that welfare recipients are morally suspect persons, criminals in waiting who are poised to abuse a public trust' (2010: 18).

Reference to New Zealand history provides no shortage of evidence of the construction of welfare beneficiaries as problematic in society. Ruth Richardson (a former Finance Minister of New Zealand) claimed that the welfare state increased poverty, created a dependent underclass, reduced income inequality and 'ended up creating ghettos where lawlessness and hopelessness are rife' (1995: 208). Richardson (1995: 209) also claimed that the benefit system created strong incentives for people to 'alter their circumstances, either to become eligible for a benefit or to remain eligible for a benefit', which they would remain on indefinitely; that the extant system resulted in the state 'subsidising bad choices' (1995: 210).

The Regulatory Impact Statement reporting on the proposed legislative changes notes that the aim of the changes is to 'provide more equitable accountability for relationship fraud' (Scott, 2012: 1). This is perhaps the most significant component of the changes: the desire to ensure that those involved, or possibly involved, in welfare fraud are 'equitably' held to account. However, there is not the same desire to achieve equitable accountability for those who commit the other 8,594 fraud, deception and other related offences in New Zealand (Police National Headquarters, 2014). If the desired outcome is fairness of treatment, then it would appear reasonable to expect the partners of others who benefit from the proceeds of crime, who knew, or ought to have known, of the offending, to be equally liable for the crime. However, there has been no suggestion made that this will 
be extended to any other form of offending or offender. Thus, those on welfare have been targeted for further discriminatory treatment in the justice system.

The primary objective of the legislative change in New Zealand appears to be deterrence, despite the relatively small number of offenders in the targeted category. There is no quantification of any potential gain to the government from the changes; there appears to be no gain from an equity perspective; and the change creates a precedent in society for targeting those receiving welfare benefits for different treatment in the justice system than the rest of society.

\section{Conclusion}

Tax evasion is a more significant social and economic issue than welfare fraud. However, welfare fraud is pursued more vigorously than tax evasion. The amended legislation provides for the partners of those who participate in welfare fraud to be constructed as criminals, despite the potential for them to have taken no positive action in assisting with the crime. The issues from the change are widespread, impacting on equity, human rights and the construction of criminals where no crime may exist.

The situation outlined throughout this article describes an example of privileged treatment for those who have more resources and power (taxpayers) and pejorative treatment of those who have less (welfare recipients). Perhaps the most important issue raised here is the targeting of a particular group in society for different treatment in the justice system. The changes in legislation provides for those in receipt of welfare, and their partners, to be treated differently to other criminals, and to others who hold debts to the state.

Cook (2002: 26) notes the 'unequal application of law, policing and punishment, which together filter the poor and vulnerable into the criminal justice system while filtering out the rich and successful'. Cook continues to raise the question of how criminal justice can be achieved in the absence of social justice. This question is particularly pertinent in the legislative amendments outlined in this article. The precedent potentially established through this change is that other vulnerable groups may also be targeted for pejorative treatment; either in the justice system or in other spheres of New Zealand society.

\section{Notes}

1 Under s.3 Social Security Act 1964, partner means a civil union partner or de facto partner. Spouse means the husband or wife of an applicant or beneficiary. Reference to partners throughout this section refers to partners or spouses.

2 A person 'ought to have known' they were benefiting from funds obtained fraudulently when 'they would have known had they made inquiries that a reasonable person would have made' (Office of the Associate Minister of Social Development, 2012). This is interpreted as the person may not actually have known they were benefiting from fraud, but should have been aware of the possibility that they were (Office of the Associate Minister of Social Development, 2012).

3 Social Security Act 1964 s.86(3).

4 Social Security Act 1964 s.86(3A).

5 This is enabled under s.66 of the Crimes Act 1961, which allows for individuals to be guilty of an offence where the individual does or omits an act for the purposes of aiding another person to commit an offence (s.66(1)). Moreover, when two or more people form a common purpose to engage in an unlawful activity, each is a party to the offence (s.66(2)). The Inland Revenue advised (under an Official Information 
Act 1982 request, received 16 September 2014) that they have not used s.66 of the Crimes Act 1961 to prosecute a partner of a tax evader.

6 Social Security (Fraud Measures and Debt Recovery) Amendment Act 2014, s.13, amending Social Security Act 1964, s.127A.

7 Social Security Act 1964, s.83AA(1)(d).

8 Information received under the Official Information Act 1982, 2 October 2014.

9 Social Security Act 1964, s.86AA(2)(a)-(b).

10 Social Security Act 1964, s.86AA(4).

11 The Inland Revenue Department advise (under an Official Information Act 1982 request) that over the past five years, there have been eleven instances where two people in a relationship have both been prosecuted for tax evasion. However, in each of these cases both parties have been charged as individual defendants and convictions follow based on the culpability of each person independently of the other. The Inland Revenue Department advise 'there was no reliance on any co-offending provision'. Data received under the Official Information Act 1982, 16 September 2014.

12 The new legislation will not amend the extant approach to domestic violence. Where a relationship is violent in nature, it is typically not considered to be a relationship in the nature of marriage for welfare purposes.

13 There is no specific provision in the Revenue Acts for the Inland Revenue Department to collected tax debt from the estate of a deceased taxpayer. However, the Commissioner of Inland Revenue will be a creditor of an estate where taxes are owing, in the same manner as other creditors, and would accordingly have a civil claim against the estate ahead of other beneficiaries of that estate. Information provided under the Official Information Act 1982, 16 September 2014. Information was requested from the Inland Revenue Department on evaded taxes recovered from the estates of decreased taxpayers. However, it was not possible for this to be provided.

14 A request was made to the Ministry of Social Development for disclosure of the frequency of recovery of overpayments from the estates of deceased welfare recipients. The request for information was denied as the information is held on individual client files and 'Ministry staff would have to manually review thousands of files', Official Information Act 1982 request, 2 October 2014.

15 Cabinet Paper released under an Official Information Act request, 2 October 2014.

16 Commentary to the Social Security (Fraud Measures and Debt Recovery) Amendment Bill.

17 Department of Prime Minister and Cabinet, CabGuide: Guide to Cabinet and Cabinet Committee Processes, http://cabguide.cabinetoffice.govt.nz [accessed 24.08.2014].

18 Department of Prime Minister and Cabinet, CabGuide: Guide to Cabinet and Cabinet Committee Processes, http://cabguide.cabinetoffice.govt.nz [accessed 24.08.2014].

19 New Zealand Bill of Rights Act 1990, s.7.

20 New Zealand Bill of Rights Act 1990, s.19.

21 Human Rights Act 1993, s.21(1)(k).

22 Released under the Official Information Act 1982, 2 October 2014. Cabinet papers titled Tackling Welfare Fraud and Welfare Debt Recovery.

23 Commentary to the Social Security (Fraud Measures and Debt Recovery) Amendment Bill, p.3/4.

\section{Acknowledgement}

The author acknowledges funding provided by the Royal Society of New Zealand Marsden Fund in the production of this article. The author is grateful for the feedback provided by three anonymous reviewers and the journal editors in the production of this article.

\section{References}

Australian Institute of Criminology (1986) 'How the public sees crime: an Australian survey', Trends and Issues in Crime and Criminal Justice, 2, 1-6. 
Borrows, C. (2013) Combatting Welfare Fraud - Main initiatives, http://www.beehive.govt.nz/ sites/all/files/20_Feb_Welfare_Fraud_Full_Initiatives.pdf [accessed 10.12.2015].

Bright, R.A. (1978) 'Dole bludgers or tax dodgers: who is the deviant?', in P. Wilson and J. Braithwaite (eds.), Two Faces of Deviance: Crimes of the Powerless and Powerful, St Lucia: University of Queensland Press.

Chunn, D. and Gavigan, S.A.M. (2004) 'Welfare law, welfare fraud, and the moral regulation of the "never deserving" poor', Social and Legal Studies, 13, 219-43.

Cook, D. (1989) Rich Law, Poor Law: Differential Response to Tax and Supplementary Benefit Fraud, Milton Keynes: Open University Press.

Cook, D. (2002) 'Where is the "justice gap"?', Safer Society Magazine, 26: 26-7.

Cook, D. (2006) Criminal and Social Justice, London: Sage Publications.

Croall, H. (2001) Understanding White Collar Crime, Buckingham: Open University Press.

Cullen, F.T., Link, B.G. and Polanzi, C.W. (1982) 'The Seriousness of Crime Revisited', Criminology, 20, 1, 83-102.

Cullen, F.T., Hartman, J.L. and Jonson, C.L. (2009) 'Bad guys: why the public supports punishing whitecollar offenders', Crime Law and Social Change, 51, 31-44.

Evans, M. and Kelley, J. (2001) 'Are tax cheating and welfare fraud wrong? Public opinion in 29 nations', Australian Social Monitor, 3, 4, 93-102.

Gupta, R. (2006) 'Perceptions of tax evasion as a crime: evidence from New Zealand', New Zealand Journal of Taxation Law and Policy, 12, 199-219.

Gustafson, K. (2009) 'The criminalization of poverty', Journal of Criminal Law and Criminology, 99, 3, 643-716.

Henman, P. and Marston, G. (2008) 'The social division of welfare surveillance', Journal of Social Policy, 37, 187-205.

Holtfreter, K., Van Slyke, S., Bratton, J. and Gertz, M. (2008) 'Public perceptions of white-collar crime and punishment', Journal of Criminal Justice, 36, 50-60.

Inland Revenue Department (2013) Annual Report 2013, Wellington: Inland Revenue Department.

Marriott, L. (2012) 'Tax crime and punishment in New Zealand', British Tax Review, 5, 62356.

Marriott, L. (2014a) Justice and the justice system: a comparison of tax evasion and welfare fraud in Australasia', Griffith Law Review, 22, 2, 403-29.

Marriott, Lisa (2014b) 'Unpaid tax and overpaid welfare: a comparison of the debt recovery approaches in New Zealand', New Zealand Journal of Taxation Law and Policy, 20, 46-70.

Marston, G. and Walsh, T. (2008) 'A case of misrepresentation: social security fraud and the criminal justice system in Australia', Griffith Law Review, 17, 1, 285-300.

McIntosh, R.K. and Veal, J.A. (2001) 'Tax evasion and New Zealanders' attitudes towards it', New Zealand Journal of Taxation Law and Policy, 7, 80-110.

Ministry of Justice (2011) Social Security (Fraud Measures and Debt Recovery) Amendment Bill, http://www.justice.govt.nz/policy/constitutional-law-and-human-rights/human-rights/bill-of-rights/ social-security-fraud-measures-and-debt-recovery-amendment-bill (accessed 6 October 2014).

Ministry of Social Development (2012) Annual Report 2011/12, Wellington: Ministry of Social Development.

Ministry of Social Development (2013a) Annual Report 2012/13, Wellington: Ministry of Social Development.

Ministry of Social Development (2013b) Social Security (Fraud Measures and Debt Recovery) Amendment Bill - Initial Briefing, Report, 18 September 2013, http://www.parliament.nz [accessed 26.08.2014).

Ministry of Social Development (2013c) Departmental Report - Social Security (Fraud Measures and Debt Recovery) Amendment Bill, Report, 26 November 2013, http://www.parliament.nz [accessed 26.08.2014).

Ministry of Social Development (2015) What We Mean by Being in a Relationship, http://www. workandincome.govt.nz/on-a-benefit/tell-us/are-you-in-a-relationship.html [accessed 09.12.2015]. 
Mosher, J. and Hermer, J. (2010) 'Welfare fraud: the constitution of social assistance as crime', in J. Mosher and J. Brockman (eds.), Constructing Crime: Contemporary Processes of Criminalization, Vancouver: University of British Columbia Press.

Nelken, D. (1997) 'White-collar crime', in M. Maguire, R. Morgan and R. Reiner (eds.), The Oxford Handbook of Criminology, 2nd edn, Oxford: Oxford University Press.

New Zealand Law Society (2013) Social Security (Fraud Measures and Debt Recovery) Amendment Bill, Submission by the New Zealand Law Society, http://www.lawsociety.org.nz [accessed 18.08.2014].

Office of the Associate Minister for Social Development (2012) Tackling Welfare Fraud, https://www.msd. govt.nz/documents/about-msd-and-our-work/work-programmes/welfare-fraud/tackling-welfarefraud.pdf [accessed 15.04.2014].

Orviska, M. and Hudson, J. (2002) 'Tax evasion, civic duty and the law abiding citizen', European Journal of Political Economy, 19, 82-103.

Police National Headquarters (2014) A Summary of Recorded and Resolved Offence Statistics, October 2014, http://www.police.govt.nz/ [accessed 06.10.2014].

Reiman, J. and Leighton, R. (2013) The Rich get Richer and the Poor Get Prison: Ideology, Class, and Criminal Justice, 10th edn, Boston: Pearson.

Richardson, R. (1995) Making a Difference, Christchurch: Shoal Bay Press.

Rossi, P., Waite, E., Bose, C. and Berk, R. (1974) 'The seriousness of crimes: normative structure and individual differences', American Sociological Review, 39, 224-37.

Scott, C. (2012) Regulatory Impact Statement: Tackling Welfare Fraud and Welfare Debt Recovery, http:// www.treasury.govt.nz/publications/informationreleases/ris/pdfs/ris-msd-twf-feb13.pdf [accessed 15.09.2014].

Sen, A. (2009) The Idea of Justice, London: Penguin Group.

Simester, A.P. and Brookbanks, W.J. (2012) Principles of Criminal Law, 4th edn, Wellington: Brookers.

Smith, G., Button, M., Johnston, L. and Frimpong, K. (2011) Studying Fraud as White Collar Crime, Basingstoke: Palgrave Macmillan.

Sutherland, E.H. (1940) 'White collar criminality', American Sociological Review, 5, 1, 1-12.

Sutherland, E.H. (1949) White Collar Crime, New York: Holt, Reinhart \& Winston.

Wacquant, L. (2009) Punishing the Poor: The Neoliberal Government of Social Insecurity, Durham: Duke University Press.

Weisburd, D., Wheeler, S., Waring, E. and Bode, N. (1991) Crimes of the Middle Classes: White-Collar Offenders in the Federal Courts, New Haven: Yale University Press.

Work and Pensions Committee (2014) The Scale of Fraud and Error and the Covernment's Response, http://www.publications.parliament.uk/pa/cm201314/cmselect/cmworpen/1082/108205.htm [accessed 09.12.2015]. 